\title{
Women of Newfangle: Co-Education, Racial Discourse and Women's Rights in Victorian Ontario
}

\section{Sara Burke}

\section{ABSTRACT}

This article argues that during the 1870s, members of the Anglo-Canadian women's movement targeted university co-education in their first radical assault on separate spheres ideology, deliberately exploiting the discourses of both individual and racial progress to openly contest established definitions of middle-class womanliness. Rather than accept the evolutionist theory that white women's contribution to the race was solely reproductive - that they were passive recipients of the benefits of male progress - reformers in Ontario argued that Anglo-Saxon women had an active, vital role to play in the ongoing work of racial advancement. Reformers linked the right of middleclass women to higher education to the much larger issue of the continued progress of the AngloSaxon race. By championing co-education, members of the women's movement were promoting a blueprint for social change in which the daughters as well as the sons of the new Dominion would assume their responsibility to regenerate Anglo-Saxon civilization.

\section{RÉSUMÉ}

Dans cet article, nous soutenons que, durant les années 1870, les membres du mouvement des femmes canadien-anglais ciblèrent la coéducation universitaire lors de leurs premières attaques radicales contre l'idéologie des sphères séparées, exploitant délibérément les discours sur les progrès tant individuels que raciaux afin de contester ouvertement les définitions établies du caractère féminin de la classe moyenne. Plutôt que d'accepter la théorie évolutionniste selon laquelle la contribution des femmes blanches à la race fut uniquement reproductive - qu'elles étaient les récipiendaires passives des bienfaits du progrès des hommes - les réformatrices ontariennes soutinrent que les Anglo-Saxonnes avaient un rôle actif et vital à jouer dans le processus du progrès racial. Les réformatrices lièrent le droit des femmes de la classe moyenne à l'éducation supérieure à l'enjeu beaucoup plus important du progrès constant de la race anglo-saxonne. Se faisant les championnes de la coéducation, les membres du mouvement des femmes favorisaient un changement social selon lequel les filles aussi bien que les garçons du nouveau Dominion assumeraient la responsabilité de regénérer la civilisation anglo-saxonne. 
The Hamilton correspondent to The Globe was surprised in March 1855 at the attentive audience which packed the Mechanics' Hall to hear an American reformer, Lucy Stone, lecture on the subject of women's rights. "Nobody expected that Miss Lucy, or indeed any other woman," he noted, "could so bravely and eloquently appear before a large number of people and speak uninterruptedly for two hours in promulgating this rather strange and modern reformation." ${ }^{1}$ At mid-century, many Victorian Canadians would have agreed with The Globe correspondent that Stone's novel views on women were entertaining but largely implausible. The following year, The Globe assured its readers that the women's movement would not become a troubling force in Canada: "The absurd demands of a small party of strong-minded women in the neighbouring Republic, for equality of political rights as well as those relating to the person and to property, will never make much headway in Canada. We are believers in 'woman's sphere."'2 Within twenty years, however, the Woman Question would become an inescapable topic of public discussion, as during the 1870 s debates over the female sphere began to challenge the dominant assumptions of middle-class Canadians. Interest peaked in 1879, when The Canadian Monthly featured the Newfangle debates, a prolonged series of disputes between residents and non-residents of "Newfangle" that explored the key issues raised by the women's rights movement: the legal, economic and political subordination of women, and, most pressingly, the contribution of AngloSaxon women to the progress of their race. In the words of an anonymous contributor to The Canadian Monthly that year, the future of women had become "[o]ne of the most interesting and important problems of modern civilization." 3 Of all the contested ideas raised by these discussions, this article argues, it was university co-education - the admission of women into men's colleges - that became the most threatening, but also the most attainable ambition of the nineteenth-century women's movement in Ontario.

The ideology of separate spheres above all was prescriptive, delineating what gender roles ought to be, defining male as well as female identities and ignoring the complex and rapidly changing social reality that increasingly characterized nineteenth-century life. "The Creator has indicated beyond doubt," the Christian Guardian argued in 1884, "that women and men are intended for different spheres in life. To woman is assigned the duties of home and motherhood; to man the burden and battle of daily manual or professional toil .... They should each, therefore, be educated with special reference to the spheres for which nature designed them, and which the habits of civilized life everywhere assign them." ${ }^{4}$ Ideas are powerful and the Victorian domestic ideology upheld a sexual division of labour, which bolstered the social, political and economic dominance of the middle classes. These ideas often contradicted the lived experience of women, many of whom spent their days working for wages in homes, schools and factories. That did not make them any less effective in prescribing an idealized reality. British arbiters of public taste like Tennyson, Patmore and Ruskin, or the more humble contributor to the Christian Guardian, did not offer proof that women could not enter the public sphere, as in many cases they already were; they simply asserted their conviction that they should not, and in doing so they referred to the 
hegemonic beliefs which underpinned middle-class power. The writings and speeches of most opponents to women's rights were characterized by this prescriptive quality, encouraging a romanticized vision of the differences between the sexes that glossed over the very real legal and economic disabilities suffered by women, particularly those whose race, class or religion placed them apart from the Anglo-Protestant elite. ${ }^{5}$ The growing gap between ideology and reality, however, opened up room for debate, promoting a flexible discussion over several decades in which ideas about women, and about the intersecting categories of race and class, were contested, reasserted, and in some cases, redefined. ${ }^{6}$ Writers in the late-nineteenth century were deeply divided over the biological and cultural significance of race and racial discourse took on multiple, often incoherent meanings, which interacted with feminist ideas in complex ways. As Janice Fiamengo has pointed out, competing interpretations of race during the Victorian period made the term itself highly unstable. ${ }^{7}$

Unlike the goal of higher education alone, which could be achieved safely within the confines of a separate college, university co-education was closely linked to women's work, or more specifically, to new professional opportunities for middle-class white women. In an 1879 essay, George Monro Grant, the principal of Queen's University in Ontario, pointed out what was by then the obvious connection between co-education and vocational competition between the sexes. "The higher education of women and such various questions connected with it as co-education in the recognised colleges of the country," he stated, "and the fitness of women for professional and industrial careers other than those to which they have been usually limited, are now discussed everywhere." ${ }^{8}$ As many began to recognize, co-education gave women the chance to study the same subjects as men and to contend with them for scholarships and class standings. By doing so, it raised the unsettling possibility that women could compete successfully with men in other aspects of public life. During the late-nineteenth century, reformers rattled the Victorian faith in separate spheres, constructing new and alternative identities for women within the male worlds of higher education, professional life and business. It was this innate radicalism, the potential to fundamentally alter prescribed gender roles, which made the idea of university co-education so profoundly disturbing.

Advocates for women's advancement in Canada, as in Britain and the United States, relied primarily on the liberal discourse of human rights articulated most coherently by John Stuart Mill, who argued that the fulfilment of individual potential was a key element in social progress. After 1860, however, the rhetoric of mid-Victorian liberalism was complicated by the view of progress conveyed by the rigid biological determinism of evolutionary theory. Inspired by such popular writers as Herbert Spencer, a growing number of Social Darwinists attacked the demands of the women's movement by arguing that the theory of separate spheres represented the most highly evolved form of human sexual relations, and as a characteristic of middle-class society was thus tangible evidence of the superiority of the Anglo-Saxon race. In their new incarnation as mothers of the race, white feminists were forced to negotiate competing interpretations of progress, to reconcile the goal of individual liberty with the demands of racial survival. 
Historians of the first-wave of the women's movement in Canada, traditionally have focused on the period after 1890 and have stressed the importance among Anglo-Canadians of maternal feminism: the belief of white reformers that their superior moral strength as wives and mothers qualified them to organize on behalf of social and political change. ${ }^{9}$ This focus has tended to draw our attention to the delayed goal of suffrage as a measure of radicalism; an indication of the degree to which rights-based feminism was submerged within women's social reform organizations. This article suggests alternatively that during the 1870 s, members of the Anglo-Canadian women's movement targeted university co-education in their first radical assault on separate spheres ideology, deliberately exploiting the discourses of both individual and evolutionary progress to openly contest established definitions of middle-class womanliness. By placing the Canadian debates within the context of international currents of thought, this study asserts that reformers in Ontario promoted a discourse on the Woman Question that linked the goals of co-education and women's professional work to more sweeping preoccupations with Anglo-Saxon racial progress.

The nineteenth-century women's movements drew ideologically on Enlightenment concepts of individual liberty and human rights; ideas which were explained convincingly in John Stuart Mill's 1869 essay, The Subjection of Women. Mill argued that while some men experienced subordination on the basis of their race, class, religion, or nationality, all women were excluded from exercising human rights on the grounds of their sex alone. Mill's most important contribution to the women's movements was his systematic articulation of the rights of both sexes to liberty and justice; a plea for the full realization of human potential, which explicitly rejected the basis of separate spheres ideology: the idea of natural or innate differences. Mill claimed that custom rather than nature had adapted the two sexes to their present functions and positions: "What is now called the nature of women is an eminently artificial thing - the result of forced repression in some directions, unnatural stimulation in others." ${ }^{10}$ This discourse of progress offered the women's movements a liberating ideology, an emphasis on individual fulfilment that embodied an apparently limitless potential for human betterment. The optimism that inspired brave minds to dismiss the fixity of women's roles, however, was forced increasingly to compete with the social evolutionists' opposing explanation of human progress.

The rise of a more aggressive imperialism and the influence of evolutionary theory shifted the ground of the Woman Question debates in a fundamental way. As the new prophets for an age enchanted by the possibilities of imperialism, evolutionist writers employed the rhetoric of science to justify the economic and political expansion of Anglo-Saxon domination. In a formative essay of 1857 entitled "Progress: Its Law and Cause," Herbert Spencer had argued that all progress, whether biological or social, followed an identical pattern, changing from a chaotic homogeneity to an ordered heterogeneity, or in other words, evolving from the simple into the complex. ${ }^{11}$ Inspired by Spencer's law of progress, other theorists affirmed that white men and women exhibited their evolutionary superiority by their greater degree of labour specialization. The division of British, Anglo-American or Canadian societies into separate male and female spheres, and the protection of women within the home, were claimed to be character- 
istics of the most fully evolved race. In this line of argument, middle-class Anglo-Saxon wives embodied womanhood in its highest evolutionary form. It was a simple step then to accuse the women's movements of attempting to sabotage rather than promote the most Victorian of accomplishments, social progress. In 1884, for example, a contributor to the Canadian journal, The Week, cited Spencer as the final authority in the battle against the women's movement. "The 'woman's rights' theory is on the face of it in flat contradiction to the modern doctrine and practice of the division of labour," John MacLean claimed. "[I]nstead of tending to assimilate the work of the woman to that of the man, the world's progress will on the contrary bring us to still further division of labour between the two, and will mark still more deeply the distinctive characteristics of each. ${ }^{12}$ " By the late-nineteenth century, the image of middle-class womanhood had become much more explicitly associated with that of a white, AngloSaxon mother, whose reproductive function made her a key participant in what Social Darwinists confidently insisted was the advancement of the higher race. ${ }^{13}$ The prescriptive nature of separate spheres ideology - what women should do - was reinforced effectively by the new biological imperative of racial preservation.

An organized Anglo-Canadian women's movement did not develop until the 1870s, in contrast to the United States and Britain, where the 1860s produced crises in the suffrage campaigns. There the evangelical anti-slavery groups of the early part of the century had established the groundwork for feminism, and until the divisive politics of the 1860s caused the movements to splinter, abolitionism had exposed both white and black women to radical ideas about human equality. ${ }^{14}$ The earliest feminist organizations in Ontario were initiated by African-Canadian women, who like black female abolitionists in the United States, made connections between racial persecution and the cause of women's rights. Carefully accommodating middle-class ideals of femininity, black women in Canada West during the 1850s struggled to build their communities, sustaining churches and schools, forming charitable and temperance societies, and fundraising for antislavery projects. ${ }^{15}$ Although more research is needed to fully explore the complex relations between anti-slavery activism and organized feminism in the Canadian context, white abolitionists do not seem to have created any parallel associations for women's rights, nor do they seem to have formed alliances with black feminists, and in this they differed remarkably from their British and American counterparts. Among Anglo-Canadian women in Ontario, the first known organization for women's rights began in 1877 as the Toronto Women's Literary Club (TWLC) founded by Emily Jennings Stowe. Like most feminists in Britain and America, Stowe had been drawn into activism by her early exposure to the liberating ideas of religious nonconformity and political radicalism. Under Stowe's direction, the TWLC connected its political goals to the improvement of women's education. ${ }^{16}$ In the preamble to the constitution of the TWLC in 1877, the members announced their intention of using the club to further their own education: "Whereas a few ladies in the City of Toronto, having felt the need of something to keep alive their interest in mental growth and development ... [have] banded themselves together to form an association for intellectual culture, where they can secure a free interchange of thought and feeling upon every subject that pertains to woman's higher education, including her moral and physical welfare." ${ }^{17}$ 
The TWLC offered an eclectic program at its weekly meetings, combining literary and cultural activities, such as musical entertainment and poetry reading - Tennyson was a favourite - with the discussion of women's suffrage, temperance and higher education. ${ }^{18}$ As president, Stowe travelled throughout Ontario speaking on women's rights, particularly on the need for equal education and the entrance of women into the professions. In the early 1880 s, the TWLC also lobbied for specific reforms, pressing the municipal and provincial governments to improve working conditions for female clerks and factory workers in Toronto and campaigning for the municipal franchise, which they won for unmarried women in 1884. In 1883, the TWLC was reconstituted as the Canadian Woman Suffrage Association (CWSA) and men were accepted as members. In 1889, after a lull in activities, the organization was renamed the Dominion Women's Enfranchisement Association. Within the circle of influential male writers, reformers and journalists connected to the TWLC during the 1880s were John W. Bengough, a political cartoonist and editor of the popular Grip magazine, and William Houston, Ontario's legislative librarian, both of whom would play key roles in publicizing the association's campaign to admit women into the University of Toronto. Most importantly, the TWLC served as an intellectual hub for Anglo-Canadian literary women and feminists. Much of the debate surrounding the Woman Question relied on the participation of such members as the journalist Sarah Anne Curzon, and the novelist Agnes Maule Machar, as well as Emily Stowe herself. ${ }^{19}$ To publicize the TWLC, in 1882 Bengough's new annual Grip-Sack published "The Sweet Girl Graduate: A Drama in Three Acts," written by Curzon as a parody of Tennyson's The Princess, in which a young woman disguises herself as a boy and attends classes at Toronto's University College. The play concludes with an allusion to the campaign of the TWLC: "Let every man and woman here to-night / Look out for those petitions that will soon / Be placed in many a store by those our friends / Who in this city form a ladies' club."20

By the late 1870s, when the TWLC was turning its attention to co-education, white middle-class women outside Canada already were making obvious inroads into men's universities: in America eight state universities, in addition to Oberlin, Antioch and Cornell, admitted female students, and in Britain the new civic institutions of the decade all adopted co-educational programs. In the early 1860s, a number of British reformers had begun a sustained campaign to win equal higher education, including university degrees for women, and in this goal they joined forces with reformers who were determined to adapt the elite Oxford and Cambridge universities to the needs of the expanding middle classes. In 1869, a small college was opened near Cambridge soon to become Girton - where women undertook the same course of study as male undergraduates, and a second, less academically ambitious college for women, Newnham Hall, was started at Cambridge in 1875. Oxford University provided similar residential accommodation for female students in 1879, with the establishment of Lady Margaret Hall and Somerville College. ${ }^{21}$ During the 1870s, British feminists became dissatisfied with the quality of education provided by the largely impoverished women's colleges and they continued to push for equal academic standards and degrees, which were attainable only by gaining access to men's universities. ${ }^{22}$ While Oxford and Cam- 
bridge remained unmoved, Britain's newer universities proved to be more willing to admit women and other outsiders to full academic privileges. Most of the civic universities from the beginning integrated women into co-educational programs of study, and in contrast to their segregation at Oxford and Cambridge, female students were able to participate more fully in university life. In 1878, the University of London, then an examining body rather than a teaching university, became the first to admit women to its degrees. From the 1870 s onward, new university colleges - later termed civic or red brick universities - were founded at Birmingham, Bristol, Leeds, Liverpool and Sheffield to prepare students for London's external degree examinations, and as they applied for their own university charters, they followed London in guaranteeing women access to their academic privileges. By 1895, all the provincial universities in England, Scotland, Ireland and Wales were admitting women to most of their programs and degrees. Faced with the problem of recruiting students to keep their programs open, civic universities could not afford to exclude women and co-education became a necessary and successful strategy for financial survival. ${ }^{23}$

From its inception at Seneca Falls in 1848, the Anglo-American women's movement had made female admission to men's colleges and professional schools one of its principal goals. Before the 1860s, there were few institutions of higher learning that admitted both men and women. The earliest of its kind, Oberlin College in Ohio, had offered co-educational programs for white and black students since 1833, and Antioch College had opened in 1853, self-consciously experimental in admitting women to the same course of study as men. ${ }^{24} \mathrm{~A}$ step toward equal higher education came in 1865, when the impressively endowed Vassar College for Women was opened in New York State. The creation of Smith and Wellesley in 1875 and of Bryn Mawr in 1885 established a tradition of elite women's colleges in the American Northeast. While the women's colleges aspired to the same rigorous academic standards as men's universities, for decades they struggled with poorly-prepared students, limited faculties, and inadequate libraries and laboratories. After the Civil War, leading Anglo-American reformers, like their British counterparts, pressed for university co-education as the only form of provision which could give women equal access, and by the 1870 s, advocates discovered that they had influential allies among other educational reformers. Resistance to the admittance of women remained profound in the men's colleges of the South and in the elite male universities of the Northeast like Harvard, Yale and Princeton. Yet a growing number of universities began to adopt co-education as one of many changes then expanding the student population and revitalizing college programs. The mid-western state universities, such as Iowa in 1855, Wisconsin in 1863 and Michigan in 1870, adopted co-education for economic as much as ideological reasons, and Cornell University in Ithaca, New York, following a private endowment for a women's residence, opened its doors to women in $1872 .{ }^{25}$

By the early 1870 s, the growing insistence of reformers on equality in higher education had prompted many hostile observers to assess the risks presented by university co-education. That middle-class white women could, and should, receive some form of higher education was accepted widely; that they should receive the identical education 
as men, and attend the same lectures and laboratories, seemed to be a radical and potentially dangerous experiment. The early success of co-education was challenging the fixity of domestic ideology, and leaving open the alarming possibility that John Stuart Mill had been right. In 1873, Edward H. Clarke, a physician and Harvard University board member, took up the task of proving that Mill was most definitely wrong and he summoned all the persuasive authority of evolutionist theory to do so. In his book, Sex in Education; or, a Fair Chance for the Girls, Clarke dismissed the entire basis of Mill's argument, asserting emphatically that abstract egalitarian ideas of individual rights and liberties had nothing to do with solving the question of woman's proper sphere. All discussions concerning women's position, he claimed, must be grounded firmly in the science of physiology. The main targets of Clarke's treatise were the new co-educational colleges, which, he believed, were already weakening the health of young women by ignoring their need to rest during menstruation, at the critical stage of their lives when their systems were most vulnerable. The efforts of reformers to provide equal education for girls ignored the inescapable fact that women and men though similar in intellectual power - were entirely different in their reproductive systems and that girls invited neuralgia, uterine disease, hysteria and other nervous derangements if they followed the same method of training as boys. ${ }^{26}$ Citing Herbert Spencer, Clarke maintained that the physical system could not do two things well at once; a young woman who overexerted her brain during her college years was therefore diverting force needed by her immature reproductive system and was risking sterility through undeveloped ovaries. "The brain cannot take more than its share without injury to other organs," Clarke warned. "It cannot do more than its share without depriving other organs of that exercise and nourishment which are essential to their health and vigor." Like other evolutionists, Clarke was concerned, in particular, with the reproductive fitness of middle-class, Anglo-Saxon women, who, as mothers of the world's most highly evolved race, were responsible for transmitting the finest attributes of white civilization. If the tendency toward the co-education of men and women continued in the same way, Clarke predicted, the sterilizing influence of this kind of training would also go on, leaving the reproduction of the race to what he termed America's "inferior classes." "The highest wisdom will secure the survival and propagation of the fittest," Clarke concluded. "Physiology teaches that this result, the attainment of which our hopes prophecy is to be secured not by an identical education, or an identical coeducation of the sexes, but by "a special and appropriate education, that shall produce a just and harmonious development of every part." 27

Sex in Education ignited an intense and prolonged controversy over co-education that soon reached Canada: the book was widely read, the first edition sold out in a week, and an additional sixteen editions were published over the next fifteen years. ${ }^{28}$ Clarke exploited scientific language to pronounce that separate female colleges were not simply a preferable model of higher education, but rather were the only institutions that could safely educate Anglo-American women without jeopardizing their biological service to the race. Members of the women's movements quickly recognized the serious threat to equal education posed by this new anchor of biology and reformers in the 
United States and Britain published substantial refutations attacking Clarke's evidence. ${ }^{29}$ In Canada, articles in the Sanitary Journal and the Canada Lancet appeared in 1874 publicizing Clarke's thesis, condemning co-education over the age of fourteen and warning, as one medical writer put it, that a girl whose brain was crowded would be "blighted at the very threshold of womanhood." ${ }^{30}$ The following year, Agnes Machar, writing under her pen-name "Fidelis," published a long critique of Clarke in The Canadian Monthly and National Review entitled, "Higher Education for Women." After reviewing Clarke's main argument, and the rebuttals by such authorities as Julia Ward Howe and Elizabeth Garrett Anderson, Machar concluded calmly that the evidence available from universities already admitting women discredited the assertions of Sex in Education. "As regards intellectual and moral considerations," she wrote, "coeducation seems, so far as it has yet been tried, to have resulted as favourably as it has physically." ${ }^{11}$ The medical profession continued to warn against co-education, and in 1877 The Globe, supporting the new campaign of the TWLC to gain access to the University of Toronto, again addressed the issue of women's physical vulnerability: "Dr. Clarke's work was completely answered from almost every possible point of view by a number of highly educated women in Great Britain and the United States, who proved as conclusively as anything can be proved from experience that the alarmist views of the theoretical physiologist were, to say the least, to a great extent baseless." ${ }^{32}$ Although the publication of Sex in Education in no way limited the rapid spread of co-educational universities - the 1870s and 1880s stand out, in fact, as the decades of most significant growth - Clarke's assessment of the dangers of masculine education for women played a formative role in constraining the experience of female undergraduates within those new institutions. He had provided ample ammunition for those who believed that competition between the sexes was unsafe as well as unwise, and other prominent physicians in Britain, America and Canada continued to pressure educators to restrict female students within the co-educational environment. ${ }^{33}$

For observers in Ontario during the 1870s, university co-education was thus a visibly successful but highly controversial model of higher education. As in Britain and America, the cause of higher education for women became linked to a more general movement among middle-class reformers to modernize the universities; to broaden the academic curriculum, strengthen the manufacturing and industrial community and bring higher learning into line with an expanding public school system. ${ }^{34}$ By 1871 , opportunities for secondary education had been increased when grammar schools were replaced by high schools or collegiate institutes. The growing number of co-educational public secondary schools meant that a larger pool of middle-class girls were able to qualify themselves for university by passing the necessary matriculation examinations. ${ }^{35}$ The creation of high schools improved the career prospects of female teachers, who had long dominated the ranks of elementary level teaching. In order to compete with men for the higher paid positions within the high schools, female teachers needed equal access to affordable university education. For this reason, a growing number of progressive-minded Ontarians interpreted the admission of women to be just one facet of a diverse attack on the province's over-privileged and irrelevant institutions of higher 
learning. One of these was William Houston, a member of the University of Toronto Senate as well as of the Canadian Woman Suffrage Association, who became a vocal champion of university reform, also pressing for the hiring of Canadian faculty and for the inclusion of new disciplines such as political economy. ${ }^{36}$ "And what about that large class of girls in this country who are compelled to earn their own living, many of them by teaching [?]" Houston demanded with characteristic impatience in The Varsity in 1880. "Without a University training they cannot hope to win any of the prizes of their profession. They cannot take charge of High Schools or become even acceptable assistants in them." 37

Although a few universities in Canada became co-educational during the 1870s, by the early 1880 s opponents could still argue persuasively that this kind of educational model was, at best, experimental and that the existence of female graduates was too much of a novelty to counter Edward Clarke's dark predictions. The Methodist Church, with a long tradition of Christian education for girls and young women at its ladies' colleges, took the lead in admitting the first female undergraduates to Mount Allison University in New Brunswick in 1872 and to Victoria College in Ontario in 1877. Initially the number of women attending these colleges was very small. During the first decade, Victoria graduated only fourteen women. ${ }^{38}$ In 1879 , Emily Stowe's daughter, Augusta Stowe, matriculated at Victoria College and, therefore, was able to enrol in its affiliate, the Toronto School of Medicine. In 1883, she became the first woman to graduate in medicine at a Canadian university. Other privately-funded, denominational universities followed the Methodists' example. In 1880, with the enthusiastic support of George Monro Grant, the new principal, Ontario's Queen's University first admitted female students as undergraduates and offered a special medical course for women in the summer, before integrating them into the regular winter session the following year. ${ }^{39}$ In 1880 , Acadia University in Nova Scotia also became coeducational, and in 1881, the provincially-funded Dalhousie University admitted women, following the example of two other maritime universities, Mount Allison and Acadia. ${ }^{40}$ But as the members of the women's movement recognized, university coeducation would spark the most opposition among those who feared the impact of female competition on the occupational choices of middle-class men. By December 1882, bitter public controversies had arisen in Ontario concerning the recent admission of female students into the Queen's Medical College and over the campaign to allow women into the provincially-funded University College of the University of Toronto. ${ }^{41}$ In a diary entry that month, Daniel Wilson, the president of University College, noted with obvious satisfaction: "[T] he papers are full of the troubles resulting at Kingston from the boasted scheme of co-education, in which they welcomed a fair candidate refused by us. The main trouble, as might be expected, is in Medicine. But in any department, when the numbers increase, trouble is sure to arise." ${ }^{42}$

During the 1870s and early 1880s, supporters of the women's movement took every opportunity to publicize their campaign for university education by engaging their opponents in vigorous debate and Ontario newspapers and periodicals frequently featured items discussing the Woman Question. Although most of the participants used 
pseudonyms, the debate clearly emanated from the circle of reformers who would become affiliated with the TWLC. Like many feminists in Britain and the United States, Canadian advocates on one level utilized the liberal rhetoric recently publicized by Mill's Subjection of Women, which rejected the authority of custom to define the scope of female work, and argued that real improvement in the human condition could only be brought about by the full realization of individual potential. Emily Stowe presented this case in a letter to the editor of The Globe in 1877: "In the world of work let her be as free to chose [sic] her vocation as is man," she urged. "Nothing could be more absurd and demoralizing than that "society" should limit the sphere of woman's action or usefulness." " 33 Similarly, Sarah Anne Curzon informed the editor of The World that the practice of paying female teachers less than their male counterparts was fundamentally unjust and rooted in women's lack of political and economic power. "We who support women's suffrage say," Curzon urged, "that the same estimate of woman that has denied her the rights of property has also belittled the value of her labor and made her remuneration low." ${ }^{44}$ Yet for Stowe and Curzon, as for other feminists, the egalitarian ideals of mid-Victorian liberalism were tempered by priorities based on class and race. Their campaigns for equality in education and employment implicitly embraced only white women of the middle-classes, who, they anticipated, would choose their vocation from among the professional and entrepreneurial options of middle-class men. Improvements in women's economic status, therefore, depended largely on gaining access to a specific category of men's academic privileges. Calling for the doors of Canada's universities to be opened to women, Stowe argued that men had usurped the educational advantages resulting from the country's progressive development, advantages to which their sisters and mothers had a just and equal right. "We ask only the same freedom in selection, and the same privileges in preparation," she claimed. ${ }^{45}$ Another female campaigner put it more bluntly in a letter to The Evening Telegram: "No reason other than sex can be assigned for my exclusion from the institutions where my brothers are welcomed." 46

By basing their claims for equal education upon their class and racial identity - by arguing, in essence, that only their sex prevented them from moving into the public sphere - these women were positioning themselves to compete with middle-class, Anglo-Saxon men for economic and political power. As most participants were well aware, the implications of this argument were fundamentally radical: competition between the sexes would inevitably break down the barriers between the public and private worlds, blurring the gendered division of labour central to middle-class Victorian ideology. Stowe could not so easily dismiss the prescriptive authority of the separate spheres ideal as the mere dictates of society. By the 1870s, evolutionist theory had filtered into popular discourse in Ontario and everywhere infused the rhetoric of social betterment and national progress with assumptions concerning the racial struggle for survival. For opponents of the women's movement, evolutionary language provided a scientific reinforcement to domestic ideology, and promoted the view that the restriction of middle-class women within the home represented the highest form of human relations, a form which both proved and ensured the superiority of Anglo-Saxon civi- 
lization. The liberal discourse of Canadian reformers increasingly left them vulnerable to the serious charge, urgently presented by Edward Clarke, that their campaign risked the continued fitness of the Anglo-Saxon race. How, then, could they effectively argue for the individual rights of middle-class women to participate in the public sphere without denying their crucial role in the superior evolution of Anglo-Saxon civilization? The solution, as will be argued below, lay in the ability of members of the Anglo-Canadian women's movement to adapt evolutionary discourse to further their own cause.

Rather than accept the evolutionist theory that women's contribution to the race was solely reproductive - that they were passive recipients of the benefits of male progress - Canadian reformers argued that Anglo-Saxon women had an active, vital role to play in the ongoing work of civilization; that the very existence of a women's movement, in fact, was itself proof that Canadian national life was evolving to a higher level. As Curzon put it: "The period thus rounded has been fruitful of many and unexpected changes in the history of humanity, but it is doubtful whether any of them have been of more importance than those immediately relating to woman. Certainly no other questions have provoked greater discussion, nor brought about more startling results, than those of woman's right to the higher education, to perfect freedom in selecting her walk in life, and to the various franchises. ${ }^{37}$ By insisting that the work of middle-class women would be essential to the development of Canadian society, advocates connected the question of university co-education to larger contemporary discussions of Canada's future as an imperial nation, and, more specifically, to interpretations of the past contributions of Anglo-Saxon women to building white civilization in the new world. Reformers were inspired by an Anglo-Saxon sense of mission, a commitment to the spread of a pan-Britannic nationalism expressed with growing vigour at Queen's University by George Monro Grant. ${ }^{48}$ As literary women, Curzon and Machar, and other friends of the TWLC, shared an interest in the use of history to illustrate their pride in the pioneering work of their female ancestors, and to use those historical constructions to attack the current limitations on female citizenship..$^{49}$ In a letter to The Globe, Emily Stowe defended the "strong-minded woman" as a figure to be admired rather than criticized, arguing that a strong woman was simply the female counterpart of the "strong-minded man," self-reliant and independent, who, by succeeding in life through industry and tenacity of purpose had earned the title of Canada's true gentleman. The source of strength in both man and woman, she urged, could be found in their moral commitment to work. "If married, she as emphatically earns her living as does her husband; and if single, and has no need to earn the bread that perisheth, she still labours from choice; she devotes her time to something useful; the world is benefited by her existence, and many will rise up and call her blessed." 50 Stowe dismissed the contention that the ability to govern, and by extension the right to participate in the public sphere, was based on superiority of physical strength; this was a barbarous relic of the past which had been entirely faded by the progressive "blaze of civilization." 51

For over three decades, opposition to the women's movement in Ontario was given its most prominent voice by the British intellectual and journalist, Goldwin Smith, 
who often wrote under the pen-name "A Bystander" in The Canadian Monthly, and, after 1883, in The Week. ${ }^{52}$ In an 1872 article in The Monthly, "The Woman's Rights Movement," Smith established the basic lines of his argument against extending political, legal and economic rights to women, an argument that would remain consistent in his writings on the subject. ${ }^{53}$ As a young Oxford academic, Smith had been inspired by the individualist philosophy of mid-Victorian liberalism, but after moving to Canada in 1871 , he became pessimistic that the democratic advances of his century would lead to a better society, and his writings reveal a growing emphasis on the need for authority to maintain moral order. ${ }^{54}$ Often contradictory and always controversial, Smith has been described as an illiberal liberal, a Victorian who drew close to an agnostic position by the end of his long life, yet who remained apprehensive that the secularizing tendencies of his age would result in moral degeneration. ${ }^{55} \mathrm{He}$ had been influenced earlier by the writings of John Stuart Mill. He had supported Mill and other radical Liberals in the campaign to expand the franchise to working men by the British Reform Act of 1867. Motivated, as he later claimed, by his own respect for Mill, Smith also had originally signed the petition to include women in the new franchise, but he soon withdrew his support from what he regarded as Mill's foolish enthusiasm for the emancipation of women. In Smith's view, Mill's passion for this cause owed much to his exaggerated and unfounded estimation of his wife's genius; The Subjection of Women, Smith once remarked was "a most pernicious book." 56

Although Goldwin Smith rejected the materialist elements of Social Darwinism with the implication that humans were under the control of "mere physical law," he nevertheless endorsed the idea of evolution as an explanation of the historical progress of human civilization. He wholeheartedly agreed that Anglo-Saxon civilization was the most highly evolved of all human societies, and like the evolutionists, he argued that the existence of separate spheres for women was both the cause and result of racial advancement. If successful, Smith warned, the women's movements would bring about nothing less than a revolution. "[S]uch a revolution," he maintained, "will be at once unparalleled in importance and unprecedented in kind. Unparalleled in importance, because female character and domestic morality lie so completely at the root of civilization, that they may almost be said to be civilization itself." ${ }^{57}$ Central to Smith's attack on the women's movements was his unflagging determination to discredit Mill and to counter Mill's assertion that women's contemporary roles were simply the artificial product of custom. Assembling eclectic examples from history, Smith attempted to prove that women's position in modern society was due to their physical dependency on men; lacking the ability to fight, and requiring protection and maintenance for themselves and their children, the role of women had evolved necessarily within the male-dominated family unit. In Smith's opinion, Anglo-Saxon men were the active force in the advancement of civilization, while women were only the passive element in social change, reaping the benefits of centuries of racial progress. He wrote: "The material civilization which women in common with men enjoy, has been produced mainly by male labour; though, of course, man could no more have continued to labour without his helpmate than he could have propagated his race without his wife." 58 
Like his friend Daniel Wilson at the University of Toronto, Goldwin Smith was in favour of separate forms of higher education for women - in the winter of 1872, he taught a course of lectures on English history for the newly-established Montreal Ladies Education Association ${ }^{59}$ - but he was deeply hostile to the adoption of co-education. During the campaign in the early 1880 s to admit women into Toronto, Smith kept up a steady bombardment against co-education in his new journal, The Week, often sparring with William Houston in the editorial pages. Smith was convinced that co-education would corrupt the natural relations between the sexes; instead of being man's helpmate, woman would become his competitor, and in this lay the true danger to the future of Anglo-Saxon civilization. For Smith, the connection between co-education and professional competition was clear, and he accused every spinster who entered the male professions of depriving bread to some married woman and her children. Echoing Edward Clarke's earlier fears of sterility in educated women, Smith scornfully dismissed the idea that co-education might lead to sexual promiscuity; on the contrary, he sniffed in 1884, those young ladies "are as safe as icebergs." ${ }^{60}$ As he gloomily watched the co-educational model spread through America, Britain and Canada, the belief that competition with men unsexed women became one of Smith's fondest themes. Writing to a female friend in 1892, he commented: "I cannot help suspecting that co-education, whatever may be its glories and beatitudes, is not particularly favourable to marriage. I perceive that our boys at Cornell rather shrink from the "co-eds," as beings not of the softer sex; indeed I can hardly imagine a boy with nerve enough to make love to a Senior Wrangler." ${ }^{1}$

Following Goldwin Smith's articles in the early 1870s, The Canadian Monthly began to publish a number of essays discussing the issue of women's rights. Agnes Machar presented one of the strongest defences of the goal of university education for women. Like Stowe and Curzon, Machar owed much to Mill. Her arguments implied that human progress should be based on the fulfilment of individual potential; that women should only be limited by their capabilities, not by the artificial restraints of custom. Far from agreeing with Smith that separate spheres were characteristic of a highly evolved civilization, she astutely pointed out that the ideal of women's domesticity was essentially prescriptive; that given Canada's rapidly changing society, it was not particularly helpful to insist that all women should become middle-class wives and mothers. "In theory, the true sphere of woman is the domestic one," Machar wrote. "But in actual life this does not come in the ordinary course of events, to all women; indeed, statistics teach us that to many it cannot. ... [W] ould it not be a real benefit to society, were every girl encouraged to learn thoroughly some one kind of realwork, be it profession, art, or handicraft; something which would bring her not only subsistence, but interesting occupation should she have to travel the journey of life alone." ${ }^{62}$ Machar's articulation of individual liberty, however, also relied on her faith in applied Christianity. In her conception of the future, women had a moral responsibility to use their abilities to improve the world in which they lived. ${ }^{63}$ " $[\mathrm{H}]$ ow much better it is for both men and women," she urged in 1878, "that both should be left entirely free to choose that life work to which they are led by the natural gifts with which God has endowed them." 64 In the view of men like Smith and Clarke, women were passive recipients of the bene- 
fits of Anglo-Saxon civilization, sheltered within the home they remained forever rooted in their biological function as mothers of the race. Machar presented readers with an alternative vision: her women were dynamic, active forces, responding to the urgent imperative to work for a new Canadian nation. In an 1879 essay, she described the great secret of progress to be a higher ideal of womanhood, which once realized, would have a profound effect "on the happiness and welfare of woman herself, and through her of the race of which she is so important a trainer." ${ }^{\prime 6}$

After the formation of the TWLC, articles on the Woman Question increased, culminating in 1879 with the Newfangle debates and no fewer than eight lengthy submissions. In May 1879, the journal published a strongly-worded and provocative article, "The Woman Question," signed only by "M." Citing Mill's Subjection of Women, the anonymous author argued that since a woman was "a self-determining creature," she had the right to enter any employment or profession and she had the right to suffrage: "She can never shape her own career, never be the arbiter of her own destiny, so long as she has no voice in framing the laws under which she lives, and to which she is amenable." ${ }^{66}$ The response to this article was explosive. For the remainder of the year, The Canadian Monthly published a heated exchange between supporters and opponents of women's rights. The authors of the articles were usually anonymous - identifying themselves only as residents or non-residents of Newfangle - but they represented the same differences of opinion expressed earlier by Goldwin Smith and Agnes Machar concerning the relation of women's work to racial progress. The most extreme attack on the women's movement appeared in the July issue and was entitled, "Some Newfangle Notions." The author, "A Woman of Newfangle," introduced herself as an aged inhabitant of the thriving agricultural township of Newfangle. Extolling the virtues of the male pioneers who had carved their community out of the bush, the writer argued that it was therefore the men only who had the right or the capacity to govern what they alone had created. "Who have dug the canals, built the railways, the steamboats, the wharves, the lighthouses?" the author asked. "Women live in and enjoy the township of Newfangle, but men have created it." Like Smith, the author asserted that pioneering Anglo-Saxon men had been the active force in the work of civilization, constructing a sheltered refuge in which to protect their women. If women wished to preserve the refined, luxurious life that had been built for them, the writer warned, then they should not interfere with the public concerns of the township. "Take away, to-morrow, the work of men, and Newfangle relapses into the barbarism from which men brought it out." ${ }^{\prime \prime}$ In the next issue of The Canadian Monthly, a "Non-Resident" of Newfangle echoed Machar's earlier objection by protesting angrily that the fictional community was far from representational, and pointing out the crucial discrepancy between ideals and reality that marked the debate. "Newfangle, it is evident, is a sort of Arcadia. The men are all honest, all chivalrous .... Women are never left widows there, with young families to rear and educate on the work of their own hands. And they have evidently never heard of 'superfluous women." The vision of male progress portrayed by Newfangle was false, the writer concluded; it took both men and women to make a world and to do the world's work. "Let both have full opportunity to do all they can and will, and the more efficient workers 
that both can supply, the better, surely, will it be for each, and for the world at large." 68 While the Newfangle debate continued briskly over the next four issues, the disagreement over the meanings of progress at its heart remained consistent, and the reformers' stubbornly repeated their arguments linking the rights of women to individual fulfilment - the right to equal education and the right to work - to the much larger issue of the continued progress of the Anglo-Saxon race. ${ }^{69}$

For Machar, as for Curzon and other literary women in Ontario, national feeling was explicitly connected to their emerging feminism. Rooted in the historic struggle of Loyalist women to carve their homes out of the wilderness, it was invigorated by the faith that Anglo-Canadian women, once unfettered by sexual prejudice, could carry that pioneering spirit into the work of the modern age. "Who can doubt," Machar had asked in 1875, "that if our Canadian young women, as a class, should become truly cultivated, earnest, high-toned, full of the noble ambition to devote life to noble work for noble ends, a very few years would strikingly demonstrate their influence in raising our young men, as a class, to a very much higher plane than that which they at present occupy?"70 In November 1879, as the Newfangle debates drew to a close, George Monro Grant published "Education and Co-Education," a forceful defence of Queen's recent decision to admit women into medicine and the arts, and the most extensive discussion of co-education yet to appear in The Canadian Monthly. Dismissing Edward Clarke's fear of overstrain as exaggerated if not ludicrous, Grant urged that university co-education represented a significant step in the progress of the race. Unlike most evolutionists, who used Spencer's "law of progress" to argue that society had evolved toward separate spheres, Grant instead insisted that equality for women would be characteristic of a more fully evolved civilization; that the women's movement, in fact, was a symptom of the highest, most complex society. "All savages are alike," he claimed. "The more advanced the civilization the greater variety among individuals. There is a higher unity, but the uniformity has gone. In an advanced civilization, then, you will no more be able to class all women as simply wives than to class all men as simply husbands." ${ }^{\prime 1}$ These reformers shared the imperialist sentiments of many AngloCanadians and their attachment to the mother country was fused to their patriotism for Canada, believing that Britain's imperialist destiny lay in the vitality and promise of the new world. By championing co-education, members of the women's movement were promoting a blueprint for social change in which the daughters as well as the sons of the new Dominion would assume their moral responsibility to regenerate Anglo-Saxon civilization.

The co-educational model was the form of provision for women most widely adopted in Canada, as it was in Britain and America. After the University of Toronto finally was forced by the Ontario government to admit women into University College in 1884, the other provincially-funded universities of New Brunswick and Manitoba followed in $1886 .^{72} \mathrm{~A}$ few universities - McGill in 1884, Trinity in 1886 and St. Francis Xavier in 1894 - opted for a separate or co-ordinate model. Armed with a generous private endowment of \$50,000 from Donald A. Smith, McGill University took what its principal, William Dawson, described as "a safe and progressive position" and estab- 
lished separate classes and residential accommodation for women in Montreal. ${ }^{73}$ By the 1890s, however, the battle for co-education had largely been fought and won. In Ontario, McMaster University started as a co-educational institution in 1890 and Western University quietly accepted women when it reopened its Arts faculty in 1895. The numbers of female students grew rapidly. In 1901 women constituted 11.6 per cent of the full-time university undergraduate enrolment in Canada and by 1930 it rose to 23 per cent. The percentage of women enrolled in Arts and Science faculties increased from 24 per cent in 1901 to 33 per cent in $1930 .^{74}$

In an age susceptible to imperial ambitions, Edward Clarke's determination to ground the entire question of women's rights in reproduction moved the debate over women's education out of the realm of John Stuart Mill's mid-century liberalism and into the crass public forum of evolutionary discourse, where all ethical positions were reduced to the test of racial expedience. It was the crude, animalistic nature of Sex in Education that most offended reformers at the time - "an intrusion into the sacred domain of womanly privacy" objected Julia Ward Howe $e^{75}$ - but it was also the farmyard aspect of his argument that would increasingly gain legitimacy, requiring advocates like Emily Stowe, Sarah Curzon and Agnes Machar to prove that intellectual development was still racially necessary even for beings so essentially reproductive in destiny. Yet the controversy over co-education underscored its inherent radicalism, drawing attention to the fact that the ultimate purpose behind the presence of women within men's programs obviously went beyond that of educating wives and mothers. Separate spheres ideology reinforced the racial and class-based dominance of middle-class men and the entrenched resistance to co-education at established universities was largely due to the highly visible integration of women and other newcomers into less prestigious institutions outside the country, particularly in the United States. At these new universities, it was becoming clear to all observers that co-education, in fact, did fundamentally alter the traditional categories of academia, of who could be an undergraduate, a researcher, or even a professor. As many reformers and their opponents perceived, university co-education had the potential to construct alternative roles for middle-class women, and by spreading rapidly throughout North America and Britain, it represented the nineteenth-century movements' most potent and ultimately successful challenge to the hegemonic structure of middle-class society. For Anglo-Canadian feminists in Ontario, the question of co-education was inseparable from the issue of women's work, symbolized as it was both by the pioneering labour of their grandmothers, and by their own vital contribution to English Canada's imperial future. Subtly adapting contemporary discourses of progress, reformers relied on Mill's liberating rhetoric of individual fulfillment while simultaneously exploiting the racial concerns of evolutionary theorists, proposing that equal education promised to make middle-class women active participants in the work of building a new Anglo-Saxon nation. "The advantages [of co-education] would be felt by the whole of society," one Canadian argued in 1880. "If women were instructed in serious thinking instead of "fancy work" ... what might we not expect for the race?"76 


\section{Notes}

"From our Hamilton Correspondent," The Globe, 15 March 1855.

"Legal Rights of Married Women," The Globe, 26 December 1856.

M., "The Woman Question," Canadian Monthly 2 (May 1879): 568.

"University Co-Education," Christian Guardian, 19 March 1884.

Lisa Tickner, The Spectacle of Women: Imagery of the Suffrage Campaign, 1907-14

(Chicago: University of Chicago Press, 1988), 160-172. For prominent literary examples of separate sphere ideology, see John Ruskin, "Of Queens' Gardens," in Sesame and Lilies (New York: Thomas Y. Crowell, n.d.; first pub. 1865), 115-116; Coventry Patmore, "The Angel in the House," in The Angel in the House Together with The Victories of Love (London: George Routledge, n.d.; first pub. 1854-56), 27-191; Alfred Tennyson, The

Princess (New York: H.M. Caldwell, n.d.; first pub. 1847). For a discussion of Canadian middle-class values at mid-century, see Andrew C. Holman, A Sense of Their Duty:

Middle-Class Formation in Victorian Ontario Towns (Kingston \& Montreal: McGill Queen's University Press, 2000), 150-169.

6 Mary Poovey has argued that historical representations of gender were often contested images, the sites at which ideas defining what it meant to be masculine or feminine were at once constructed and challenged. Mary Poovey, Uneven Developments: The Ideological Work of Gender in Mid-Victorian England (Chicago: University of Chicago Press, 1988), $1-23$.

7 Janice Fiamengo, "Rediscovering our Foremothers Again: Racial Ideas of Canada’s Early Feminists, 1885-1945," Essays on Canadian Writing 75 (Winter 2002), 85-117. Reprinted (abridged) in Mona Gleason and Adele Perry, eds., Rethinking Canada: The Promise of Women's History, 5th ed. (Don Mills: Oxford University Press, 2006), 144-162.

8 Principal [G.M.] Grant, "Education and Co-Education," Rose-Belford's Canadian Monthly and National Review, 3 (November 1879): 509.

9 Cecilia Morgan, "'Old Ontario' Through the Lens of Feminist Scholarship, 1970s1990s," Atlantis 25, no. 1 (Fall/Winter 2000): 93; Vijay Agnew, "Canadian Feminism and Women of Color," Women's Studies International Forum 16, no. 3 (1993): 217-227; Afua Cooper, “Constructing Black Women's Historical Knowledge," Atlantis 25, no. 1 (Fall/Winter 2000): 39-50.

10 John Stuart Mill, The Subjection of Women (New York: Prometheus Books, 1986), 27. For the influential ideas of Mill's wife, Harriet Taylor Mill, see Harriet Taylor, "Essay on Marriage and Divorce," and "Enfranchisement of Women," in Alice S. Rossi, ed., Essays on Sex Equality, by John Stuart Mill and Harriet Taylor Mill (Chicago: University of Chicago Press, 1970), 84-87, 91-121.

11 Herbert Spencer, "Progress: Its Law and Cause," in Essays: Scientific, Political, and Speculative (New York: D. Appleton, 1901), 8-62. For Spencer's later writings on the relation between the role of women and social evolution, see Herbert Spencer, The Principles of_Sociology (Westport, CT: Greenwood Press, 1975, originally pub. 1876), 609-610, 713, 731, 757-758; and Herbert Spencer, The Study of Sociology (New York, D. Appleton, 1902, first pub. 1873), 340-348.

12 John Maclean, "The Woman Question in its Relation to Progress," The Week (6 March 1884).

13 Louise Michele Newman, White Women's Rights: The Racial Origins of Feminism in the United States (New York: Oxford University Press, 1999), 10; Vron Ware, Beyond the Pale: White Women, Racism and History (London: Verso, 1992), 37-44, 119-120; Anne McClintock, Imperial Leather: Race, Gender and Sexuality in the Colonial Contest (New York: Routledge, 1995), 1-17, 46-48. For discussions of racism and imperialism in the Canadian context, see Sarah Carter, Capturing Women: The Manipulation of Cultural 
Imagery in Canada's Prairie West (Montreal \& Kingston: McGill-Queen's University Press, 1997), 3-47; Mariana Valverde, “'When the Mother of the Race Is Free,': Race, Reproduction, and Sexuality in First-Wave Feminism," in Franca Iacovetta and Mariana Valverde, eds., Gender Conflicts: New Essays in Women's History (Toronto: University of Toronto Press, 1992), 3-26.

14 Sandra Stanley Holton, Suffrage Days: Stories from the Women's Suffrage Movement (London: Routledge, 1996), 7-25; Martin Pugh, The March of the Women: A Revisionist Analysis of the Campaign for Women's Suffrage, 1866-1914 (Oxford: Oxford University Press, 2000), 27; Jill Liddington and Jill Norris, "One Hand Tied Behind Us": The Rise of the Women's Suffrage Movement (London: Virago, 1978), 20-46; Shirley J. Yee, Black Women Abolitionists: A Study in Activism, 1828-1860 (Knoxville: the University of Tennessee Press, 1992), 136-154; Newman, White Women's Rights, 3-69. For abolitionism in Canada, see Michael Gauvreau, "Reluctant Voluntaries: Peter and George Brown; The Scottish Disruption and the Politics of Church and State in Canada," The Journal of Religious History 25, no. 2 (June 2001): 141-142; J.M.S. Careless, Brown of the Globe, vol. 1, The Voice of Upper Canada, 1818-1859 (Toronto: Macmillan, 1959), 102-103; Allen P. Stouffer, The Light of Nature and the Law of God: Antislavery in Ontario, 18331877 (Montreal \& Kingston: McGill-Queen's University Press, 1992), 108-141, 189; Robin W. Winks, The Blacks in Canada: A History, 2d ed. (Montreal \& Kingston: McGill-Queen's University Press, 1997), 252-271.

15 By 1854, black women in Canada West had formed two literary societies, one in Chatham and one in Windsor, both of which combined educational and cultural interests with activism for temperance and abolitionism. Under the editorship of Mary Ann Shadd Cary, between 1853 and 1859 the Provincial Freeman provided a public forum for the discussion of political concerns, including women's rights. See, for example, Provincial Freeman, 6 May 1854, 10 June 1854, 17 March 1855, 12 May 1855, 15 August 1857. For the social activism of African-Canadian women during the 1850 s, see Shirley J. Yee, "Gender Ideology and Black Women as Community-Builders in Ontario, 1850-70," Canadian Historical Review 75, no. 1 (March 1994): 53-73; Tamari Kitossa, "Criticism, Reconstruction and African-Centred Feminist Historiography," in Njoki Nathani Wane, Katerina Deliovsky and Erica Lawson, eds., Back to the Drawing Board: African-Canadian Feminisms (Toronto: Sumach Press, 2002), 95-99; Peggy Bristow, "Whatever you raise in the ground you can sell it in Chatham': Black Women in Buxton and Chatham, 185065," in Peggy Bristow, et al., eds., "We're Rooted Here and They Can't Pull Us Up": Essays in African Canadian Women's History (Toronto: University of Toronto Press, 1994), 108.

16 For biographical information on Stowe, see Mary Beacock Fryer, Emily Stowe: Doctor and Suffragist (Toronto: Dundurn Press, 1990); Gina Feldberg, "Emily Howard (Stowe) Jennings," Dictionary of Canadian Biography; Constance B. Backhouse, "The Celebrated Abortion Trial of Dr. Emily Stowe, Toronto, 1879," Canadian Bulletin of Medical History 8, no. 2 (1991): 160-163.

17 Quoted in Heather Murray, "Great Works and Good Works: The Toronto Women's Literary Club, 1877-83," Historical Studies in Education 11, no. 1 (1999): 75.

18 Queen's University Archives (QUA), Emily Howard Stowe Fonds, A. Arch 3078, Scrapbooks, unidentified newspaper clippings concerning the Toronto Women's Literary Club.

19 Although Machar lived in Kingston, she was a corresponding member of the TWLC. Murray, "Great Works and Good Works," 85-91; Heather Murray, Come, bright Improvement! The Literary Societies of Nineteenth-Century Ontario (Toronto: University of Toronto Press, 2002), 107-116, 139-141; Edith M. Luke, "Woman Suffrage in Canada," The Canadian Magazine, 5 (1895), 328-330; Christina Burr, "Gender, Sexuality, and Nationalism in J.W. Bengough's Verses and Political Cartoons," Canadian Historical Review 83, no. 4 (Dec. 2002): 549-551. 
20 S.A.C. [Sarah Anne Curzon], “The Sweet Girl Graduate,” The Grip-Sack, A Receptacle of Light Literature, Fun and Fancy (Toronto: Grip Printing \& Publishing, 1882), 54. For Bengough's support of the women's movement, see J.W. Bengough, "Mr. Stotenbottel on Woman Suffrage," The Grip-Sack, A Receptacle of Light Literature, Fun and Fancy (Toronto: Grip Printing \& Publishing, 1883), 51-55.

21 Paul R. Deslandes, “The Foreign Element': Newcomers and the Rhetoric of Race, Nation, and Empire in 'Oxbridge' Undergraduate Culture, 1850-1920," Journal of British Studies 37 (Jan. 1998): 54-90; Rita McWilliams Tullberg, Women at Cambridge (Cambridge, U.K.: Cambridge University Press, rev. ed. 1998).

22 James C. Albisetti, "Un-learned Lessons from the New World? English Views of American Coeducation and Women's Colleges, c. 1865-1910," History of Education 29, no. 5 (2000): 473-489; Janet Howarth and Mark Curthoys, "The Political Economy of Women's Higher Education in Late Nineteenth and Early Twentieth-Century Britain," Historical Research 60, 142 (1987): 208-231; Elizabeth Seymour Eschbach, The Higher Education of Women in England and America, 1865-1920 (New York: Garland Publishing, 1993), 120-124.

23 Carol Dyhouse, No Distinction of Sex? Women in British Universities, 1870-1939 (London: UCL Press, 1995), 1-55; Julie S. Gilbert, "Women Students and Student Life at England's Civic Universities before the First World War," History of Education 23, no. 4 (Dec. 1994): 405-422.

24 Ronald W. Hodeland, "Coeducation of the Sexes at Oberlin College: A Study of Social Ideas in Mid-Nineteenth-Century America," Journal of Social History 6, no. 2 (Winter 1972-73): 160-176; John Rury and Glenn Harper, "The Trouble with Coeducation: Mann and Women at Antioch, 1853-1860," History of Education Quarterly 26, no. 4 (Winter 1986): 481-502.

25 Barbara Miller Solomon, In the Company of Educated Women: A History of Women and Higher Education in America (New Haven: Yale University Press, 1985), 43-61, 76, 144-145; Eschbach, Higher Education of Women, 60-81, 99-119, 104-105, 153-159.

26 Edward H. Clarke, Sex in Education; or, a Fair Chance for the Girls (Boston: James R. Osgood, 1873), 11-30, 61-117, 118-161.

27 Clarke, Sex in Education, 43, 140 [italics in original].

28 Sue Zschoche, "Dr. Clarke Revisited: Science, True Womanhood, and Female Collegiate Education," History of Education Quarterly 29, no. 4 (1989): 547; Rosalind Rosenberg, Beyond Separate Spheres: Intellectual Roots of Modern Feminism (New Haven: Yale University Press, 1982), 1-27.

29 Julia Ward Howe, ed., Sex and Education: A Reply to Dr. E.H. Clarke's "Sex in Education" (New York: Arno Press, 1972; first pub. 1874); Elizabeth Garrett Anderson, "Sex in Mind and Education: A Reply," The Fortnightly Review 15 n.s. (May 1874).

30 Quoted by Wendy Mitchinson, The Nature of Their Bodies: Women and Their Doctors in Victorian Canada (Toronto: University of Toronto Press, 1991), 84.

31 Fidelis [Agnes Maule Machar], "Higher Education for Women," Canadian Monthly 7 , no. 2 (Feb. 1875): 147. Agnes Maule Machar would become most well-known for her social reform novel of 1892, Roland Graeme, Knight. Machar was a regular contributor to the Canadian Monthly and to several other periodicals, and after 1877, she was a corresponding member of the TWLC. The daughter of a principal of Queen's College, Machar had received a rigorous education, and her broadly-based knowledge of languages and literature later was strengthened by contact with prominent intellectuals and reformers, including her close friend George Monro Grant. For discussions of Machar's varied career as a writer and social reformer, see Dianne Hallman, "Rights, Justice, Power: Gendered Perspectives on Prohibition in Late Nineteenth-Century Canada," History of Intellectual Culture 2, no. 1 (2002): 1-14; Dianne M. Hallman, "Agnes Maule Machar 
on the Higher Education of Women," Historical Studies in Education 13, no. 2 (2001): 165-182; Ruth Compton Brouwer, "The 'Between-Age' Christianity of Agnes Machar," Canadian Historical Review 65, no. 3 (1984): 347-370; Fiamengo, "Rediscovering our Foremothers Again," 150-153.

32 "Co-Education of the Sexes," The Globe, 7 Nov. 1877.

33 Zschoche, "Dr. Clarke Revisited," 545-569; Newman, White Women's Rights, 86-95; Rosenberg, Beyond Separate Spheres, 1-27; Joan N. Burstyn, "Education and Sex: The Medical Case Against Higher Education for Women in England, 1870-1900," Proceedings of the American Philosophical Society 117, no. 2 (April 1973), 79-89.

34 David John Ayre, "Universities and the Legislature: Political Aspects of the Ontario University Question, 1868-1906” (Ph.D. diss., University of Toronto, 1981), 1- 15; Paul Axelrod, The Promise of Schooling: Education in Canada, 1800-1914 (Toronto: University of Toronto Press, 1997), 88-103.

35 Paul Axelrod writes that in 1900, fewer than 10 per cent of fifteen- to nineteen-year-olds were attending high school in English Canada. Axelrod, Promise of Schooling, 60-63. R.D. Gidney and W.P.J. Millar maintain, however, that the majority of grammar schools by the late 1860 s were attended by boys and girls of the middling classes rather than of the elite. R.D. Gidney and W.P.J. Millar, Inventing Secondary Education: The Rise of the High School in Nineteenth-Century Ontario (Montreal \& Kingston: McGill-Queen's University Press, 1990), 183-195.

36 University of Toronto Archives, William Houston, B2004-0002/001, Letterbook of William Houston, William Houston to Mrs. Curzon, 12 Feb. [188?], William Houston to W. Mulock, 25 Jan. 1882, William Houston to Dr. Schurman, 31 July 1884 . See also, Sara Z. Burke, Seeking the Highest Good: Social Service and Gender at the University of Toronto, 1888-1937 (Toronto: University of Toronto Press, 1996), 15-17.

37 William Houston, “Co-Education in University College," The Varsity, 11 Dec. 1880.

38 Johanna M. Selles, Methodists and Women's Education in Ontario, 1836-1925 (Montreal \& Kingston: McGill-Queen's University Press, 1996), 166, 161-168; John G. Reid, "The Education of Women at Mount Allison, 1854-1914," Acadiensis 12, no. 2 (Spring 1983): 3-33; Barbara Ibronyi, Early Voices: Women at Victoria (Toronto: Victoria University, 1984).

39 Queen's College Journal2, no. 9 (6 March 1880); Queen's College Journal3, no. 1 (30 Oct. 1880); Queen's College Journal3, no. 12 (7 May 1881).

40 Judith Fingard, “College, Career, and Community: Dalhousie Coeds, 1881-1921," in Paul Axelrod and John G. Reid, eds., Youth, University and Canadian Society: Essays in the Social History of Higher Education (Montreal \& Kingston: McGill-Queen's University Press, 1989), 26-50.

41 In December 1882, male students at the Queen's Medical College in Kingston boycotted classes and threatened to pursue their studies elsewhere, unless the women students were requested to withdraw. The boycott resulted in the establishment in 1883 of a separate Women's Medical College at Kingston, and in the opening of a rival school in Toronto, later named the Ontario Medical College for Women, sponsored by Emily Stowe. In 1916, one of the female students, Elizabeth Smith Shortt, wrote her account of the controversy. QUA, Faculty of Medicine Fonds, Women's Medical College, A. Arch. Series 10, coll. 1184, "Historical Sketch of Medical Education of Women in Kingston, Canada," by Elizabeth Smith Shortt. For the extensive press coverage, see, for example, The Globe and The Daily Mail, 11-20 Dec. 1882.

42 University of Toronto Archives, Langton Family, B65-0014/004(02), Journal of Sir Daniel Wilson, 19 Dec. 1882.

43 QUA, Emily Howard Stowe Fonds, A. Arch 3078, Scrapbooks, Letter to The Globe, "Woman's Rights," dated 27 Nov. 1877, signed "Reformer," handwritten identification "E." 
44 QUA, Emily Howard Stowe Fonds, A. Arch 3078, Scrapbooks, Letter to The World, "Woman and the Franchise," n.d., signed "S.A.C."

45 QUA, Emily Howard Stowe Fonds, A. Arch 3078, Scrapbooks, Letter to The Globe, "Woman's Rights," dated 27 Nov. 1877, signed "Reformer," handwritten identification "E."

46 QUA, Emily Howard Stowe Fonds, A. Arch 3078, Scrapbooks, Letter to The Evening Telegram, "The Question of Woman's Rights," n.d., signed "Progress."

47 QUA, Emily Howard Stowe Fonds, A. Arch 3078, Scrapbooks, Unidentified letter, "Professional Women," n.d., signed "S.A.C."

48 William Lawson Grant and Frederick Hamilton, Principal Grant (Toronto: Morang \& Co, 1904), 395-419; D.B. Mack, "George Monro Grant," Dictionary of Canadian Biography.

49 Ruth Compton Brouwer, "Moral Nationalism in Victorian Canada: The Case of Agnes Machar," Journal of Canadian Studies 20, no. 1 (Spring 1985): 90-108; Cecilia Morgan, "History, Nation, and Empire: Gender and Southern Ontario Historical Societies, 890-1920s," Canadian Historical Review 82, no. 3 (Sept. 2001): 491-528; Dianne M. Hallman, "Cultivating a Love of Canada through History: Agnes Maule Machar, 1837-1927" in Creating Historical Memory, Alison Prentice and Beverly Boutilier, eds., (Vancouver: University of British Columbia Press, 1998), 25-50; Beverly Boutilier, "Women's Rights and Duties: Sarah Anne Curzon and the Politics of Canadian History," in Creating Historical Memory, 51-74.

50 QUA, Emily Howard Stowe Fonds, A. Arch 3078, Scrapbooks, Letter to The Globe, "One of the Strong-Minded," dated 5 Nov. 1877, signed "For Progress and Reform," handwritten identification "Emily."

51 QUA, Emily Howard Stowe Fonds, A. Arch 3078, Scrapbooks, Letter to The Globe, "Woman's Rights," dated 27 Nov. 1877, signed "Reformer," handwritten identification "E."

52 Goldwin Smith severed his connection to The Canadian Monthly in December 1874, so that he could devote more time to the short-lived weekly, The Nation. The first issue of The Week appeared in December 1883, founded and partly owned by Goldwin Smith, to provide an outlet for young Canadian writers of varying political and social opinions. Until the beginning of 1885, Smith wrote a weekly comment on events. See Elisabeth Wallace, Goldwin Smith: Victorian Liberal (Toronto: University of Toronto Press, 1957), 72-79, 90.

53 See, for example, Goldwin Smith, "Woman's Place in the State," The Forum 8, no. 52 (1890): 515-530; "Woman Suffrage," in Essays on Questions of the Day: Political and Social (New York: MacMillan, 1893), 183-218.

54 Paul T. Phillips, The Controversialist: An Intellectual Life of Goldwin Smith (Westport, CT: Praeger Publishers, 2002), 87-92; 145-178.

55 Malcolm Ross, "Goldwin Smith," in Claude T. Bissell, ed., Our Living Tradition: Seven Canadians (Toronto: University of Toronto Press, 1957), 29-47. See also, Ramsay Cook, "Goldwin Smith," Dictionary of Canadian Biography; and Ramsay Cook, The Regenerators: Social Criticism in Late Victorian English Canada (Toronto: University of Toronto Press, 1985), 26-40.

56 Quoted by Arnold Haultain, Goldwin Smith: His Life and Opinions (Toronto: McClelland \& Goodchild, n.d.), 171; Goldwin Smith, Reminiscences, ed. by Arnold Haultain (New York: MacMillan, 1910), 360.

57 A Bystander, “The Woman's Rights Movement," Canadian Monthly 1, no. 3 (March 1872): 249.

58 Bystander, "Woman's Rights Movement," Canadian Monthly 1, no. 3 (March 1872): 251; Goldwin Smith, "Female Suffrage," Canadian Monthly 6, no. 1 (July 1874): 73, 75. 
59 Bystander, "Woman's Rights Movement," Canadian Monthly 1, no. 3 (March 1872): 252; Report of the Montreal Ladies Educational Association, Second Session, 1872-73 (Montreal, 1873), CIHM no. 11089.

60 [A Bystander], The Week 1, no. 12 (21 Feb. 1884). See also "A Bystander's" comments in The Week 1, no. 10 (7 Feb. 1884); The Week 1, no. 15 (13 March 1884); The Week 1, no. 16 (20 March 1884); Smith, "Female Suffrage," Canadian Monthly 6, no. 1 (July 1874): 71-72.

61 Goldwin Smith to Mrs. Winkworth, 26 July 1892, in A Selection from Goldwin Smith's Correspondence, ed. by Arnold Haultain (Toronto: McClelland \& Goodchild, n.d.), 248.

62 Fidelis, "Higher Education for Women," Canadian Monthly 7, no. 2 (Feb. 1875): 153 [italics in the original].

63 Dianne M. Hallman, "Agnes Maule Machar on the Higher Education of Women," Historical Studies in Education 13, no. 2 (2001): 177; Fiamengo, "Rediscovering our Foremothers Again," 150-153.

64 Fidelis, "Woman's Work," Canadian Monthly 1 (Sept. 1878): 311.

65 Fidelis, "The New Ideal of Womanhood," Canadian Monthly 2 (June 1879): 661. See also Fidelis, "A Few Words on University Co-Education," Canadian Monthly 8 (March 1882): 313-319; Agnes Maule Machar, "The Higher Education of Women," The Week 7, no. 4 (27 Dec. 1889): 55-56.

66 M., "The Woman Question," Canadian Monthly 2 (May 1879): 573, 575.

67 A Woman of Newfangle, "Some Newfangle Notions," Canadian Monthly 3 (July 1879): $82,83$.

68 A Non-Resident of the Same, "Newfangle and its Opinions," Canadian Monthly 3 (Aug. 1879): 203, 205, 206 [italics in the original].

69 See A Woman of Newfangle, "Another Word or Two," Canadian Monthly 3 (Sept. 1879): 296-302; A Non-Resident, "Newfangle Again," Canadian Monthly 3 (Oct. 1879): 410416; Our Old Friend of Newfangle, "Some Last Words on the Woman Question," Canadian Monthly 3 (Nov. 1879): 529-535; A Non-Resident of Newfangle, "A Brief Summing up on the Woman Question," Canadian Monthly 3 (Dec. 1879): 620-626.

70 Fidelis, "Higher Education for Women," Canadian Monthly 7 (Feb. 1875): 145 [italics in the original].

71 Grant, "Education and Co-Education," Canadian Monthly 3 (Nov. 1879): 516.

72 Sara Z. Burke, "New Women and Old Romans: Co-education at the University of Toronto, 1884-95," Canadian Historical Review 80, no. 2 (June 1999): 219-241; Donna Yavorsky Ronish, "Sweet Girl Graduates: The Admission of Women to English-Speaking Universities in Canada in the Nineteenth Century" (Ph.D. diss., University of Montreal, 1985).

73 J. William Dawson, Report on the Higher Education of Women, October 1884, CIHM o. 02606; for the admission of women into McGill University, see Margaret Gillett, We Walked Very Warily: A History of Women at McGill (Montreal: Eden Press, 1981).

74 Alyson E. King, "The Experience of the Second Generation of Women Students at Ontario Universities, 1900-1930" (Ph.D. diss., University of Toronto, 1999), 74; Ronish, "Sweet Girl Graduates," 559.

75 Howe, introduction to Sex and Education 7.

76 Andrew A. Stevenson, The Varsity, 18 Dec. 1880. 